\title{
"Prince of Circassia": Sefer Bey Zanuko and the Circassian Struggle for Independence
}

\author{
Yahya Khoon
}

\begin{abstract}
Prince Sefer Bey Zanuko (d. 1860) was probably the most famous and well documented Circassian leader during the war against Russia in the first half of the nineteenth century. Nevertheless, no thorough research has been carried out to date on him in English. This article deals with Sefer Bey's crucial role in guiding, assisting and leading the Circassian resistance to the Russian conquest of the Northwest Caucasus in the nineteenth century and sheds new light on a topic that has been almost completely neglected in Western research so far.
\end{abstract}

Keywords: Circassians, Caucasus, Crimean war, Ottoman Empire, Russia

\section{'Çerkesya Prensi': Sefer Bey Zanuko ve Çerkesya Bağımsızlık Mücadelesi}

Özet

Prens Sefer Bey Zanuko'nun (öl. 1860) 19. yüzyılın ilk yarısında Rusya'ya karşı savaşan Çerkes liderlerin muhtemelen en ünlüsü olduğu ve hakkında kayıtlı en çok bilgiye sahip olduğumuz lider olduğu söylenebilir. Bununla birlikte Zanuko hakkında bugüne kadar ciddi bir çalışma yapılmamıştır. Bu makale, Sefer Bey'in Kuzeybatı Kafkasya'nın Rusya tarafından işgaline karşı oluşan Çerkes direniş hareketi içerisinde oynadığı kritik rolü (yardım, yönlendirme ve liderlik etme) irdeleyerek Batı akademik dünyasında neredeyse tamamen göz ardı edilmiş bir konuya dikkat çekmektedir.

* Dr. Yahya Khoon, The Open University of Israel, Middle Eastern Studies, khoon@netvision.net.il. 
Yahya Khoon

\section{Introduction}

This paper proposes to discuss the long anticolonial struggle of Sefer Bey Zanuko, who was later to become an Ottoman pasha, for Circassian independence, an often-neglected topic in the history of the Caucasus, and his role as a Circassian national leader. While the resistance to the Russian conquest of the Northeast Caucasus in the nineteenth century and its leaders received a lot of attention in Western and Soviet (and post-Soviet) research - several books and dozens of articles have been published on the topic over the last decade -the Northwest Caucasus dimension has been almost completely ignored.

By focusing on the resistance in the eastern part of the Caucasus, and at times by claiming that the unity of the narrative would have been destroyed (Baddeley 1908, 8), or that research would have been an anticlimax to the movement's dramatic end in the East (Baddeley 1908 , 8), researchers paid little attention to other parts of the Caucasus. The Northwest Caucasus not only remained closely linked to the other parts of that region and to the Islamic world in general during the so-called Caucasian War, but the fierce resistance of its indigenous people to Russian imperial policy and colonial rule also "began earlier, lasted longer and ended more disastrously for those who were fighting to defend their freedom" (Henze 1992, 62).

\section{Early Years}

Sefer Bey Zanuko (Zanoğlu or Zanzade, in Turkish) was descended from the Circassian princely family of Zan near Anapa in Circassia (FO195/443). There was a lack of agreement about the sub-ethnic group his family belonged to. Some believed that they belonged to the Kheaks (or Khegaks), who subsequently mixed with the Natukhays and the Shapsughs (Karlgof 1860, O politicheskom, 547). Others thought that they were of Haituko in Chemguy and of Halashuko near Sukhum-kale, and of the same princely stock (which formed the fraternity of Bulatuko) -held to be one of the most ancient and princely in all Circassia (Bell 1840, 233). 
Sefer Bey began his career inauspiciously. His father, Mehmed Giray Bey, ${ }^{1}$ died when he was young (Bell 1840, 269-270; BOA, C. AS. 790/33473). In 1807, after the capture of the fortress of Anapa by the Russian troops, the local population delivered Sefer Bey as hostage (amanat) to the Russian authorities (Karlgof 1860, O politicheskom, 547). Soon afterwards, he was sent to Odessa and studied at the Rishelevski Lyceum, where he learned to speak, read, and write Russian. He then started serving in the Russian army, but did not get along with the commander of his regiment and fled to the mountains (Felitzyn 1904, 27).

According to the British traveller James Stanialaus Bell, soon afterwards "he set sail for Egypt to join the [Circassian] Mamluks, with whom he remained, sharing in all the fierce warfare amid which their power was broken up. (Bell 1840, 233)" ${ }^{\prime 2}$ He then returned to Circassia and married a Nogai princess. Sefer Bey soon returned to Anapa, which had again been conquered by the Ottomans (Bell 1840, 233). He soon decided to join them in the struggle against their common enemy, the Russians. He sailed to Istanbul and offered his services to the Porte (BOA, C. ML. 24/1104; HAT. 653/31957). Meanwhile, he joined the service of Anapa's governor (vali), Hajji Hassan Pasha, ${ }^{3}$

${ }^{1}$ For Mehmed Giray Bey activities and for his relations with the Ottomans, see Istanbul, Başbakanlık Osmanlı Arşivi (hereafter: BOA), Hatt-ı Hümayun [HAT. ]: 27/1301, 29 Zilhicce 1197 [25 November 1783]; 186/8730, 20 Zilhicce 1205 [29 August 1791]; 188/8982, 29 Zilhicce 1205 [29 August 1791]; Cevdet Dahiliye [C. DH. ]: 326/16267, 23 Şaban 1195 [14 August 1781]; 29/1434, 21 Cemâziyel-evvel 1206 [16 January 1792]; 271/13543, 7 Şevval 1206 [29 May 1792]; 26/1260, 19 Rebîul-âhir 1220 [17 July 1805]; Cevdet Askeriye [C. AS. ]: 461/19233, 3 Zilkâde 1195 [21 October 1781]; 1175/52380, 20 Zilkâde 1201 [3 September 1787]; 700/29363, 22 Cemâziyelâhir 1206 [16 February 1792]; Cevdet Saray [C. SM. ], 120/6033, 27 Ramazan 1206 [19 May 1792]; Cevdet Eyalet-i Mümtaze [C. MTZ. ]: 19/907, 3 Receb 1201 [21 April 1787]; 4/160, 7 Şevval 1206 [29 May 1792]; Cevdet Maliye [C. ML. ], 48/2213, 7 Şevval 1206 [29 May 1792].

${ }^{2}$ On the massacre of the Mamluks (1811) by Muhammad (Mehmed) 'Ali Pasha of Egypt, see Jane Hathaway 2009, 285-288.

${ }^{3}$ For Hacı Hasan Çeçenoğlu or Çeçenzade Pasha al-Trabzoni's (as he was known among the Circassians) activities in the northwest Caucasus, see BOA, Hatt-ı Hümayun [HAT. ], 1087/44240, 29 Zilhicce 1243 [12 July 1828]; Akty 
under whom he became second in command (Bell 1840, 233), ${ }^{4}$ with the rank of Colonel (Karlgof 1860, Magomet-Amin, 95).

During the Russian-Ottoman War of $1828-1829,{ }^{5}$ the Russians recaptured the fortress of Anapa, took Sefer Bey prisoner and transferred him to Odessa (Felitzyn 1904, 17). He resided there until the end of the war, which ended with the Treaty of Adrianople in 1829. Having been set free, he returned to Circassia, commenced travelling as a "political missionary" and became one of the most influential leaders of the Circassian resistance for independence (Slade 1837, 195-196).

\section{Circassian Ambassador to Istanbul}

After the Treaty of Adrianople, conditions in Circassia worsened. According to article 4 of the treaty, the Ottoman Empire was compelled to abandon its positions and rights on the Circassian coast (FO 78/1336). This opened the door for the Russians to establish military forts on the Black Sea coast and link them by land lines to the Cossack settlements (stanitsas), which were established on Circassian territories along the Kuban River. ${ }^{6}$ In fact, this development indicated the beginning of systematic Russian colonialism in the region.

The Circassian tribal society was divided into many subgroups, with their own dialects, beliefs, customs, traditions, interests,

Sobrannye Kavkazskoi Arkheograficheskoi Kommissiei (hereafter: $A K A K$ ), Tiflis, Vol. X, 1885, p. 234, document No. 240, Serebriakov's Diary, 11 [23] December 1852, No. 2133; Khan-Girei, Cherkesskie Predaniia (Nal'chik: Ël'brus, 1989), pp. 263-269; Bell, Vol. 1, p. 179; idem, Vol. 2, p. 241; Askhad losufovich Chirg, Razvitie obshchestvenno - politicheskogo stroia adygov Severo-Zapadnogo Kavkaza, konets XVIII - 60-e gg. XIX v. (Maikop: Kachestvo, 2002), pp. 87-88.

${ }^{4}$ For a detailed description of Sefer Bey's activities during this period, see BOA, Hatt-ı Hümayun [HAT. ]: 918/39971, 11 Rebîul-âhir 1243 [1 November 1827]; 1103/44583, 1087/44240, 1087/44250C, 1102/44564, 29 Zilhicce 1243 [12 July 1828 ] respectively.

${ }^{5}$ On the Russo-Turkish campaign of 1828-1829, see Allen and Muratoff 1953, 23-45.

${ }^{6}$ For the origin and history of the Cossacks, see Baddeley 1908, 3-17. 
alliances and feuds (Spencer 1837, 343-344). They had no choice but to concentrate their efforts and to rise above the traditional and ethnographic level of the tribe. Meanwhile, the confederated Circassian princes decided to send Sefer Bey as their representative to Istanbul (Spencer, 1838, 86; FO 195/443). In the spring of 1831, a 200strong Circassian delegation headed by Sefer Bey left for the Ottoman capital but before he left he had made his countrymen swear a solemn oath on the Qur'an, never to lay down their arms and continue resistance to the Russian Army till his return (Chirg 2002, 95), "with a view to moving the sympathy and procuring, if possible, the assistance of the Porte and the Western powers in the unequal struggle which they continued to maintain against Russia" (FO 195/443).

In Istanbul, he first addressed the Porte, but with no effect (Slade 1837, 196). The Ottoman Empire was not interested in breaking off the Treaty with Russia and in assisting the Circassians openly. All Sefer Bey managed to achieve, however, was a promise that a quantity of arms and ammunition would be supplied secretly (Chirg 2002, 95). Furthermore, he solicited the help of his former enemy, Muhammad [Mehmed] Ali Pasha of Egypt,also in vain. Disappointed, Sefer Bey settled in Samsun, where he carried on his attempts to find real support for the Circassians (Slade 1837, 196). At the same time, he maintained contacts with his countrymen in Circassia, sending them letters, and sometimes smuggling arms and ammunition (Longworth 1840, 113; Chirg 2002, 95).

While in Samsun, Sefer Bey had the good fortune to meet a man who opened the door to the dominant Western power in the east to fill the vacuum created, namely David Urquhart (Daud Bey), a Scot and the first Briton to become a supporter of the Circassian cause. In concert with the Circassian prince, Urquhart set sail for Circassia in the summer of 1834, "ostensibly to investigate the possibilities for British trade, but his interests extended far beyond the commercial field" (Henze 1992, 82-83). This short trip in fact "would remain the most famous encounter between highlanders and their Western supporters throughout the entire period of the Caucasus wars" (King 1863, 248). 
Soon after his arrival, a large assembly of Circassians (zefes) gathered at night in the village of Astagay near Anapa, on the orders of Sefer Bey, in order to express "their feeling towards Russia, and their hopes from England" to Urquhart (FO 881/618; Chirg 95). The Circassians submitted a petition, signed by eleven chiefs, to the King of Great Britain, William IV, asking him to be compassionate and assist them in their struggle. No reply was forthcoming, however (FO $881 / 618)$. In 1835 , and a gain in 1836 , the Circassians, guided by Sefer Bey, who had been invited to leave Samsun and move to Istanbul for a while, appealed to England both for protection and for the encouragement of commerce. This would enable them to defy Russia. The British ambassador in Istanbul returned the letter, unopened, and recommended, in reply to their second letter, that the Circassians should try to make peace with Russia (FO 881/618).

\section{An "Exiled Ambassador"}

By 1836, after several failed attempts to convince the British Government to give direct or indirect aid to the Circassians, a disappointed Sefer Bey was driven from Istanbul, following urgent remonstrances by the Russian ambassador in the Ottoman capital, and sent off to Tatar Pazarcık, a small town in the neighborhood of Edirne (Longworth 1840, 113). His crime, for the Russian ambassador, was "assisting his countrymen by every means he could command" (Urquhart 1837, 73). The events were of such importance that the ambassador went in person to the Porte, and declared that "either he or the obnoxious Circassian must quit his post" (Urquhart 1837, 7374). Having no choice, the Sultan, was forced to expel Sefer Bey.

Subsequently, Sefer Bey resided in Edirne, with a monthly allowance from the Sultan. The exiled Circassian prince, however, maintained contact with his countrymen, and "his recommendation had ensured honourable reception to any travellers professing an interest in their independence" (Slade 1867, 223-224). ${ }^{7}$ In late 1836,

\footnotetext{
${ }^{7}$ For more details, see BOA, Cevdet Zabtiye [C. ZB. ], 58/2859, 30 Receb 1253 [30 October 1837]; Cevdet Dahiliye [C. DH. ], 49/2413, 27 Zilhicce 1253 [24 March 1838]; Hatt-ı Hümayun [HAT. ]: 1179/46586, 1063/43640, 29 Zilhicce
} 
with the encouragement of Urquhart a number of Britons, such as Bell and his brother, tried on the schooner Vixen to run through a blockade of the Circassian coast of the Black Sea, ordered in 1831 by the Russian government, albeit unsuccessfully. The British vessel was captured by the Russians, which led to an embarrassing international incident (Richmond 2013, 50).

In 1838, and again in 1839, the Circassians filed additional petitions, this time to Queen Victoria, but all these efforts were in vain, too. The British Ambassador in Istanbul informed Sefer Bey that "Her Majesty's Government cannot give the Circassians any assistance" (FO 97/344). In January 1843, a Circassian deputation passed through Istanbul on its way to London with the objective of soliciting the good offices of the British Government, and thus affect some arrangement for peace with Russia. As he had been instructed, however, the British ambassador in Istanbul dissuaded them from persevering in their project (FO 97/344). Soon afterwards, Sefer Bey arrived incognito in Istanbul upon a similar errand. He was found out and ordered to return to Edirne immediately (FO 97/344).

From 1843 to 1853, while Sefer Bey continued to live in exile far away from Circassia, the state of affairs in his homeland changed. The Great Powers' unfulfilled promises of relief to the Circassian resistance effort, along with ideological failures, leadership crises and indifferent masses, constituted a fertile ground for a generation of Islamic activism. In the vacuum created by these internal social and political developments, the Khalidi branch of the Naqshbandiyya Sufi brotherhood started spreading its orthodox-activist ideals among the Circassians. Imam Shamil, the famous leader of the militant Sufi movement, and his emissaries to the Circassians, provided religious leadership, both ideologically and practically. Headed by Muhammad Amin, these deputies established not only an administrative system based on the Shari'a, which had replaced customary law (khabze), but

1253 [26 March 1838]; 694/33477, 4 Rebîul-evvel 1254 [28 May 1838]; 1421/58100, 27 Rebîul-evvel 1254 [20 June 1838]; 754/35626, 5 Rebîul-âhir 1254 [28 June 1838]. 
also played an important role in organizing and leading the Circassian resistance to Russia. ${ }^{8}$

Meanwhile, and after a long wait, Sefer Bey's wish was finally fulfilled. On 4 October 1853 the Ottoman Empire officially declared war on Russia. Documents showed how the Ottoman command, together with North Caucasian mountaineers, wanted to promote a joint offensive against Russia in the spring of 1854 (Yama'uchi 1985, 7-10). To prepare for the planned operation, the Porte recruited men with Circassian roots into the Ottoman forces by awarding them advanced ranks, titles, and salaries (FO 195/443). One of these key men was Sefer Bey. Rumors on the approaching war persuaded him to ask the Porte to release him from exile and to offer it his services (BOA, i. DH. 282/17709). Despite Sefer Bey's advanced age, the Porte

${ }^{8}$ For Hajī Muhammad's and Sulaymān Efendī's activities between 1842 and 1846, see $A K A K$, Vol. X, pp. 415-417, 418-419, 573, 684, document no. 384, 385, 526, 634, "Military Operations in the Caucasus in 1845, Shāmil's Proclamation to the Circassians, " September 1845, Vorontsov to the Tsar, 26 August [7 September], Budberg to Vorontsov, 17 [29] October 1850, No. 107 (secret) respectively; ibid. , Vol. XII, p. 698, document No. 598, Kozlovskii to Bariatinskii, 16 [28] October 1856, No. 2982; Dvizhenie, p. 445-8, 451, 473-5, 480-1, 483, 519-22, document nos. 233, 235, 247, 254, 256, 285, 287, Commander of Caucasian Line to Neidhardt, 7 [19] February 1844, Chernyshev to Neidhardt, 22 February [6 March] 1844, Neidhardt to Chernyshev, 28 April [10 May] 1844, Richter to Krukovskii, 24 September [6 October] 1844, Krukovskii's memorandum, 13 [25] October 1844, Labyntsev to Vorontsov, 26 July [7 August], Sunja Line commander's Diary, within 22 July [3 August] 1846 respectively; D. Sokolov, "Khadzhi Magomet (Spodvizhnik Shamilia. Istoricheskaia spravka), "Kubanskii Sbornik (Ekaterinodar: Vol. XI, 1905), pp. 53-64; G. N. Prozritelev, "Posol'stvo ot Shamilia k Abadzekham," in A.N. Osmanov, ed. Mukhammad-Amin I Narodno-Osvoboditel'noe Dvizhenie Narodov Severo-Zapadnogo Kavkaza $v$ 40-60 gg. XIX veka (Sbornik Dokumentov i Materialov), (Makhachkala: Jupiter, 1998), pp. 48-53; A. Panesh, “Deiatel'nost' Khazhi-Magometa i Suleimana-Ëfendiia na Severo-Zapadnom Kavkaze, " in Cherkesiia v XIX veke (Maikop: 1991), pp. 92-107. 
trusted him because of his influence over the Circassians and in October 1853 recalled him to Istanbul from his exile in Edirne. ${ }^{9}$

\section{Governor of Circassia}

Soon after Sefer Bey's arrival in Istanbul opposing views appeared among decision makers in the Ottoman Empire about the establishment of a "competent leadership" in Circassia. The position of Muhammad Amin, the popular and energetic naib of Imam Shamil to Circassia, raised concern with the Ottoman authorities. The main reasons were that he had gathered strength among the local population in the Northwest Caucasus and that he spoke in praise and acted on behalf of Shamil, making almost no mention of the name of the Sultan. ${ }^{10}$ Some ministers at the Porte feared that the naib had gained too much strength and was acting too independently, and as such would not break his loyalty to the Imam easily and would not consent to acting on the side of and under the direct leadership of the Sultan (Lapinskii 1863, 285).

One consequence of this was the need to find a leader who was less independent and more loyal to the Sultan to be placed at the head of all Circassian groups. During the discussions in the Ministerial Council two opposite proposals were raised by the two brothers-inlaw of the Sultan. While the Minister of War Damad Mehmed Ali Pasha supported the appointment of Sefer Bey as governor of Circassia, Fethi Ahmed Pasha, the muşir (marshal) of Tophane (the arsenal of ordinance), recommended the naib for this position and even offered to send him regular military forces, artillery, and money. Finally, these contradictory proposals resulted in both accepting the compromise proposed by the third member of the council, the Ottoman foreign minister, Rashid Pasha. Sefer Bey was appointed to the post while Behcet Efendi, a Circassian by origin and the former personal secretary of the minister, joined him as his assistant (Lapinskii 1863, 286-288). This decision not only reflected the lack of knowledge of part of the Ottoman decision makers regarding the

9 Budak mentions that Sefer Bey returned to Istanbul in September. See Budak 1993, 152.

${ }^{10}$ On Muhammad Amin, see Khoon 2010, 154-155. 
recent sociopolitical conditions in Circassia, but would ultimately also be seen to be fundamentally false.

In 1853, during the months of October and November Russian punitive expeditions were dispatched against the Shapsughs and the Natukhays. The Russians destroyed all the surrounding villages and the food that had been stored by the local population for the coming winter, near the Pshishe River in the Shapsugh territories (AKAK, 338). The Russian minister of war urged the Russian command to carry out further offensive actions against the Circassians (AKAK, 625-626).

Meanwhile, Sefer Bey, the intended governor of Circassia on behalf of the Sultan, who had been made a pasha ${ }^{11}$ with the rank of mirmirân, ${ }^{12}$ along with Behcet Efendi, decided in coordination with the Ottoman ministry of war to deliver messages by proxy to Muhammad Amin and the Circassian leadership. Sefer Bey sent two emissaries, Mehmet Efendi and Haci Ahmed Ağa, to Trabzon. The orders of the Ottoman ministry of war to the governor of Trabzon, Mehmed İsmet Pasha, were clear: to ensure safe passage and conveyance of both emissaries "by boat (sandalairkâben) from Trabzon to Circassia" (Yama'uchi 1985, 9-10).

On 29 October two envoys of Sefer Bey, equipped with supplies and ammunition, sailed from Trabzon (Yama'uchi 1985, 10) and landed on the coast between Ghelenjik and the Vulan River in the Shapsugh territories. ${ }^{13}$ Although the Ottoman message to Muhammad Amin was brief, at least in writing, it was essentially clear. As part of the preparations for the operation the Ottoman Empire was planning to carry out in spring 1854, the naib was expected to show determination, recruiting fighters and preparing the

${ }^{11}$ A certain Ismail Bey, who was awarded the rank of ıstabl-ı amire müdiri, joined in with Sefer and Behcet Pashas. See BOA, Hariciye Nezâreti Siyasî Kısım [HR. SYS. ], 1345/94, 22 Safer 1270 [24 November 1853]; Sadâret Divan-ı Hümayun Kalemi [A. DVN. ], 94/2, 25 Safer 1270 [27 November 1853].

${ }^{12}$ Mirmirân is a pasha of the second class who governs a province.

${ }^{13}$ On the arrival of two sailing vessels (çektirme) to that region, see the following report in $A K A K$, Vol. X, p. 642, document No. 587, Kukharenko to Vorontsov, 28 November [10 December] 1853, No. 7450. 
ground for the long-awaited arrival of Sefer Bey, the new Circassian governor on behalf of the Sultan.

Concerning HE [Sefer Paşa]'s men, Mehmet Efendi and Haci Ahmed Ağa, who have today set out for that destination, and as their oral communications will bring to the notice of Your Excellency and reveal in detail, the expectation is entertained by your humble servant that you will make all efforts and persevere for the complete and fruitful results of the undertaking, as your piety and honour demands (Yama'uchi 1985, 10).

Sefer Bey's envoys transferred a letter to his son Karabatir (Ibrahim Bey, according to Ottoman sources), ordering him to inform the Bzhadugh, a Circassian sub-ethnic group, to start a war against Russian alliance with the Ottomans. He also asked him to persuade all devoted Muslims "who believe in Allah and Muhammad" to turn their weapons against Russians (AKAK, 642). Although the letter was intended for the Bzhadugh, Sefer Bey ordered them to forward it to other subgroups as well, such as the Hatiquay, Chemguy, Makhosh, Besleney, Kabardians, and the Nogais (AKAK, 642). ${ }^{14}$ He apologized for not being able to address each group separately, as the local costume demanded. Meanwhile, he wrote to the Shapsugh, Abzakh, and Ubykh and urged them to defer to Muhammad Amin, if he indeed protected the public interest and to follow him until his arrival with Ottoman military forces. He demanded the local population to gather 1000 horses and a similar number of oxen, as the forces intended to land on the coast with cargo, weapons and ammunition, which they would bring from Istanbul (AKAK, 642). ${ }^{15}$

On 27 March 1854, the fact that Britain and France formally joined the Ottomans in the war led Russia to take on a defensive position.

${ }^{14}$ As mentioned earlier, Sefer Bey's wife was not a Circassian but a Nogai princess by origin. It is quite possible that his appeal to the Nogais was related to these family relations.

15 This information was received by one of the Abzakh notables named Ahmad (Effendi) Beyshuq. The man turned to the Russian authorities and offered his allegiance to them. For his letter dated October 1853, see Gosudarstvennom Arkhive Krasnodarskogo Kraia (hereafter: GAKK), f. 261, op. 1, d. 1263, p. 79. 
The Russians were forced to pull back their fleet to Sevastopol. Furthermore, they abandoned the forts gradually, with the exception of Anapa and Sujuk-Kale (Novorossiysk), and pulled back their garrisons from the eastern shores of the Black Sea beyond the Kuban River (Clowes 1901, 399-402). These developments boosted the morale of the Circassians. After more than two decades of waiting they were finally given the golden opportunity to win their freedom and independence.

In May, the Ottoman fleet sailed from the Bosphorus, with Sefer Bey and Behcet Pasha carrying messages and gifts from the Sultan for the Circassian leaders. ${ }^{16}$ About 300 other Circassians, merchants or exiles, many of them accompanied by their families, took the opportunity to return to their homeland under the Ottoman banner. The ships also carried twelve European officers to instruct the Circassians, a complete field battery, including artillery, small arms, ammunition, and other supplies (Slade 1867, 224). Sir Adolphus Slade (Mushaver Pasha), who was serving as an advisor to the Ottoman navy, added:

The gallant admirals could not, or would not, be brought to see the difference between an expedition and a consignment - the difference, in the eyes of a semi-barbarous people, between landing envoys, auxiliaries, arms and ammunition from a squadron with attendant pomp and circumstance, and dropping them like ordinary passengers and goods from crowded transports. Better far, but for appearance sake, have sent them all back to Constantinople (Slade $1867,241)$.

On 24 May the expedition to Sukhum-Kale set out in appalling conditions, as described above. Both Circassians of rank and commoners finally landed, throwing their arms and goods ashore. Sefer Bey returned to his homeland as a refugee, while Behcet Pasha and others landed at Adler (Slade 1867, 242-243; AKAK, 274-278). This

\footnotetext{
${ }^{16}$ About his promotion to the title of pasha, see BOA, Hariciye Nezâreti Siyasî Kısım [HR. SYS. ], 1345/94, 22 Safer 1270 [20 November 1853]; Sadâret Divan-ı Hümayun Kalemi [A. DVN. ], 94/2, 25 Safer 1270 [27 November 1853].
} 
left a negative impression on the local population, which felt betrayed by Ottoman policies. "The Porte promised us," they said, "a Turkish fleet with troops, but never sent it" (Slade 1867, 242-243). This serious blow to the prestige of the Ottoman Empire not only complicated its future plans on the Caucasian front, but also increased the involvement of its allies in that region.

\section{Sefer Pasha vs. Muhammad Amin}

Sefer Bey, who had meanwhile been appointed governor by the provisional war council (Meclis-i Muvakkat-ı Harbiye) (Budak 77), returned to Circassia as the "civillian and military Governor of all the Circassian provinces situated between the Black Sea and the River Kuban" (FO 195/443; FO 881/1441). However, in parts of Circassia, in which his influence had never prevailed much, he had to contend with Muhammad Amin (FO 881/1441), who was clearly disappointed with the Porte's decision to send the famous old prince back to Circassia. ${ }^{17}$

Soon after his arrival, Sefer Bey invited Muhammad Amin, as well as other notables representing various Circassian subgroups, to attend a national assembly at Sukhum-Kale. During the meeting, the new governor demanded, on behalf of the Sultan, that they send him fighters in order to reinforce the imperial forces in Batum for the planned operation against Russian forces in the district of Mingrelia. The Circassians, however, were deeply concerned that this would merely be a cover for recruiting them into the Ottoman regular forces and thus compelling them to leave their homeland without any protection. Hence they refused to accept Sefer Bey's request (Karlgof 1860, 96). John A. Longworth, ${ }^{18}$ the British agent in Circassia, gave an account of the changed conditions in a report in 1855 :

\footnotetext{
${ }^{17}$ On this, see Khoon 2012, 1-12.

18 John Augustus Longworth, the author of $A$ Year among the Circassians (published in 1840), was appointed Consul at Monastir, 29 September 1851; was employed on Special Service in Epirus and Thessaly, from March to July 1854; also on Recruiting Service in Albania in April and May 1855; and was sent on Special Service to Circassia on 13 April 1855. On this, see The Foreign Office List (London: Harrison, 59, Pall Mall, 1856), p. 54.
} 
During the 25 years, however, that he [Sefer Bey] had been absent, a decided change had taken place in the political character of these districts, nearly all his influential contemporaries of a former period had disappeared from the scene, and the new generation had been very much Russianised. The bulk of the population had for some years maintained open intercourse with the garrisons on the coast, and many of them had taken service with them as irregular cavalry. In a national point of view, they have been thoroughly demoralized, and it remains to be seen of the old spirit of patriotism can be revived (FO 881/1441). ${ }^{19}$

Sefer Bey bitterly disappointed the Porte's high hopes for him. He again invited Muhammad Amin, accusing him of having falsified the data dispatched to the Ottoman government about his successes in recruiting fighters and about the willingness of the local population to join the Ottoman war effort against Russia. The naib tried, in vain, to make excuses, arguing that the Circassians were unwilling to take part in a war conducted outside their homeland and would never agree to participate in such a war (Karlgof 1860, 96). He put the blame on the Ottoman agents, headed by Sefer Bey, accusing them of causing a deep rift among the people, instead of cooperating with him and joining him in a war against a common enemy (FO 195/443).

In fact, it was a power struggle that reflected two different sociopolitical concepts. On the one hand, Muhammad Amin, Shamil's emissary, preached for the orthodox religious ideals of the Naqshbandiyya Sufi brotherhood, challenging its class structure and one of its most sacred symbols, that of princes and nobles, in order to enforce a "new order" based on the Shari'a. On the other hand, the representative of the Ottoman Sultan, the Circassian aristocrat Sefer Bey, saw as his main ambition the restoration of the rights and authorities of princes and nobles that had been limited by Muhammad Amin, but which they were entitled to according to Circassian local laws and customs. The clash for leadership was inevitable. Muhammad Amin did not intend to remain passive with regards to what he saw as the Ottoman agent's intention to abuse his authority to weaken his influence among the Circassians. In July 1854,

\footnotetext{
${ }^{19}$ See the same in ibid. , FO 881/1441, No. 8.
} 
Muhammad Amin sailed to Istanbul to seek imperial support from the Sultan (FO 195/443). He too was made pasha with the rank of mirmirân and returned to Circassia. ${ }^{20}$ In fact, by delegating authority to both these figures, so opposite in nature and tendencies, the Porte increased the pair's preexisting rivalry (Osman Bey 1877, 171-172). Indeed, the result was not long in coming. In March 1855, near the river of Shebzh, the first of three bloody battles between the supporters of Sefer Bey and Muhammad Amin took place (BOA, HR. TO. 424/37; Chirg, 155).

For a long time Sefer Bey remained inactive at Sukhum-Kale. It was only after the Russians had evacuated Anapa and Sujuk-Kale that he ventured to appear in the northern provinces of Shapsugh and Natukhay (FO 881/1441). On 10 June 1855, he arrived at Anapa with a small personal escort and took possession of the abandoned fortress (Slade 1867, 395). In his report to the British secretary of state for foreign affairs, Longworth gave warning that the Porte not only intended to reoccupy and strengthen its position in the places evacuated by the Russians along the coast, "but extending her authority, temporal as well as religious, over the whole of Circassia" (FO 195/443).

The Porte, which sought to strengthen its position in that region, at long last realized that its own policy was causing disharmony among the Circassians. In fact, the recognition and support shown Sefer Bey and Muhammad Amin further deepened the social divide and prepared the ground for local leadership struggles. To prevent further clashes between the two rivals, a decision was made based on an imperial Firman (decree) to place them under the authority of Mustafa Pasha, a Circassian by origin from the neighborhood of Anapa (Osman Bey 1877, 171-172), who had been virtually appointed governor-general of Circassia (FO 195/443), and now carried the flamboyant title of the 'commander of the Circassians territories and Batum's corps', as clarified in the following instructions (Osman Bey 171-172):

\footnotetext{
20 For his promotion to the rank above, see BOA, İrade Dahiliye [i. DH.], 305/19355, 5 Zilkâde 1270 [30 July 1854]; Kazem-Bek 1860, 238 ; Slade 1867, 203; Budak 1993, 77.
} 
It has become necessary to appoint an intelligent and able person to protect and guard well the coast of Sokoum [Sukhum] ... to provide for the welfare of the people inhabiting Circassia under my Imperial shadow; to establish unity among the numerous tribes in Circassia... [you] are now appointed, in pursuance of my Imperial decree, to be Military Governor of the aforesaid coast of Sokoum, and Commander-in-chief of the army of Batoum ... you will administer well the people of Circassia; you will guard and protect well their place; you will exert yourself diligently with the chiefs and influential Circassians. . . ${ }^{21}$

The Ottoman control and occupation of fortresses that had been evacuated by the Russians along the Circassian coasts, more particularly since the evacuation of Anapa, began to show signs of increased security. Within a short time, many Shapsughs and Natukhays, especially the nobility, which had fled the "leveling doctrines" of Muhammad Amin and taken refuge and even served with the Russians, returned to Circassia en masse, giving their support to Sefer Bey (FO 78/1243).

Meanwhile, as a result of the convention signed by the Ottoman, Britain, and French commanders-in-chief in the Crimea, a task force was sent to Anapa to destroy the seaward defenses, and, if necessary, to repair the fortifications on the land side. Instructions were decisive and were based on the assessment that the Russian might thereafter reoccupy the strategic fortress. On 14 July, the British ship Leopard arrived in Anapa, with 80 French artillerymen, under the command of two officers of the artillery and engineers, on board. But Sefer Bey has expressed opposition to the planned actions, declaring that "he could not give his consent till he had received orders to that effect from his superior of command, Mustapha Pasha" (FO 881/1441). His language, according to Longworth, was "most offensive and imprudent in this respect; and he talked of rising 20,000 Circassians for the defense of Anapa against the detachment which had been sent to destroy the seaward fortifications" (FO 881/1441).

\footnotetext{
${ }^{21}$ For the full contents of the Firman, which the Porte gave to that officer, see FO 881/618, 67.
} 
The fall of Sevastopol into Allied hands in September 1855 made it possible for the Ottoman Empire to shift the war efforts to the Caucasian front, but it was too little, too late. The silence that surrounded the "Circassian Question", especially by the Ottoman Empire, which had kept Circassia out of the Treaty of Paris in March 1856, caused great disappointment among the Circassians, who had expected the Ottoman Empire to protect its Muslims and their national rights. The news that peace had been signed produced much excitement and thousands of mountaineers gathered at Anapa, where Sefer Bey resided. Several hundred Circassian leaders met to discuss and draw up a message to the Sultan, the Queen of England, ${ }^{22}$ and the emperor of France, asking in vain that the independence of their country be recognized. ${ }^{23}$ As said before, not only did the Ottoman Empire's silence leave Circassia outside the peace agreement politically, but its policy failure during the Crimean War (1853-1856) also left the population of Circassia divided and confused.

The country continued to be led by two rival leaders both of whom were in the service of the Ottoman Sultan. The appointment of Muhammad Amin as the civillian governor, instead of Sefer Bey, set off a new struggle for power (FO 78/1243). In May 1856 another battle took place on the banks of the Sup River (Chirg 2002, 158). The internal conflicts came to an end only after the intervention of Circassian leaders, who offered to settle the dispute peacefully. Their proposal called for the two rivals to sail to Istanbul and for the man who would win the support of the Sultan to become the actual governor of Circassia. The two rivals agreed to the compromise and swore a solemn oath to fulfill it. While the naib sailed to the Ottoman capital accompanied by a Circassian delegation that included representatives from several subgroups that were located on the north-eastern shores of the Black Sea, Sefer Bey apparently failed to keep his promise and remained in Circassia (Karlgof 1860, 100; Kazem-Bek 1860 238; AKAK, 697).

22 For the English translation of this petition, see FO 881/618, 89-90, Inhabitants of Circassia to the Queen, 7 Sha'ban 1272 (15 April 1856).

${ }^{23}$ The Illustrated London News, 24 May 1856. 
Although Muhammad Amin accused Sefer Bey of breaching the oath, it seems that the latter's lack of responsiveness was actually a result of the changed conditions after the Crimean War (Kazem-Bek 1860, 238). Under the terms of the peace agreement in Paris, the Ottoman Empire began to withdraw its forces from Anapa in June 1856, while Sefer Bey stayed behind, despite his desire to reach Istanbul, on the secret order of the Porte. When the order was given to burn the fortress and destroy it completely, the last 200 Ottoman regular soldiers who remained in Circassia boarded an Ottoman ship and retreated from the area. ${ }^{24} A$ short while later, Sefer Bey abandoned the Anapa region with his family, crossed the river of Shebzh (Kerashev 1995, 109), and resettled on the banks of Shapsykhua river (Lapinskii 1863, 329). Probably driven by a genuine desire to take advantage of the absence of Muhammad Amin, he took steps to achieve the Circassian political unity under his leadership. He ordered the destruction of the anchorage of Tuapse, which served as a supply center for the Abzakh and Bzhadugh supporters of the naib, "a cheater [who] has no authorization from the Sultan", and he even called for the assassination of "the pretender" (Kerashev 1995, 109).

During the second half of 1856, Sefer Bey corresponded with the Russian military authorities, looking for ways to find peace. ${ }^{25}$ Meanwhile, a delegation of his supporters returned to Circassia on a British warship, carrying long-awaited news. According to Russian reports based on information disclosed by local spies, Sefer Bey's supporters boasted about how the Sultan had shown them every courtesy; he had also approved the appointment of Sefer Bey as governor of all the mountaineers and had emphasized that from then on everyone must obey him. ${ }^{26}$

\footnotetext{
${ }^{24}$ On the causes and the Ottoman dispute came after the ruin of Anapa, see Lapinskii, Vol. 1, 328-329; BOA, İrade Dahiliye [i. DH. ], 352/23196, 23 Şevval 1272 [27 June 1856].

${ }^{25}$ On Sefer Bey's letter to Filipson, see ibid, p. 110.

${ }^{26}$ On the gifts and medals which the Sultan gave to the delegation members, see $A K A K$, Vol. XII, 705-706, document No. 602, Bariatinskii to Gorchakov, 14 [26] November 1856, No. 115.
} 
In fact, the status quo ante was preserved. Since each side claimed the crown against the backdrop of the Ottoman foreign policy, a renewed conflict between the parties was only a matter of time. In January 1857, the followers of Sefer Bey and Muhammad Amin clashed again near Tuapse, with heavy losses on both sides. Karabatir, the son of Sefer Bey, who headed his father's followers, took credit for the victory. Sefer Bey publicly declared that he had received letters from the Sultan and had been ordered to put an end to the power of the naib and to unify all the Circassian subgroups under his authority (AKAK, 719).

\section{Conclusion}

Despite the peace agreement signed by all parties, the Russians suspected a continued involvement of the Ottoman and British governments in Circassian affairs (Kerashev 1995, 111; Chirg 2002, 159). Notwithstanding the vigorous efforts of the Russian ambassador to Istanbul and the exertion of pressure on the Porte to prevent the planned military expedition to Circassia ${ }^{27}$, in late February 1857, a British steamer named Kangaroo docked at Tuapse, carrying about 150 soldiers of various nationalities. ${ }^{28}$ Consequently, the Russian envoy presented a confidential memorandum to His Majesty, the Sultan, in which he complained that the encouragement and assistance given to the Circassians during the Crimean War did not cease after the peace agreement, and that the Ottomans never proclaimed or published anything in Circassia, with regard to friendship and goodwill between the two governments:

That Sefer Bey and Mehemed Emin [Muhammad Amin] Pasha, been subjects of the Porte, who have been in its service, and attained military rank, and whoever else may be in Circassia, be

${ }^{27}$ See, BOA, I. HR. 140/7327; FO 881/1441, 18-19; FO 881/618, 95; Lapinskii 18-19.

${ }^{28}$ The British steamer "Kangaroo" arrived at Tuapse on 27 or 28 February 1857. On the contradictions between the dates, see FO195/528, Stevens to Stratford, Trebizond, 3 March 1857, No. 1 (Slave Trade and Confidential); Lapinskii 1863, 30. 
invited to come to Constantinople; and should they obey the Imperial order, they are to be deprived of their rank and allowances. $^{29}$

In view of these developments, a special council meeting was convened in Istanbul to decide how to deal with the Russian ambassador's complaint. Its recommendations were submitted for the Sultan's consideration, approval, and validation. The councils (majlis) recommended taking concrete steps to prove the authenticity of the Ottomans intentions, and to renew its bonds of friendship and mutual trust with Russia. The recommendations also included a ban on the shipment of arms and ammunition to Circassia, complete severance of the relationship (alâkaları kulliyyan kat) with Sefer Bey and Muhammad Amin, and depriving both pashas of their military rank and salaries (BOA, i. MMS. 9/366).

In May 1857, Muhammad Amin returned to Istanbul, and fell straight into the Ottoman trap. He was arrested and exiled to Damascus under Russian pressure, escaped and returned to Circassia. ${ }^{30}$ At the time Sefer Bey was living in one of the villages in the Natukhay region on the river Sukko, near Anapa, and without losing hope of gaining the support of the Ottoman Empire continued to complain about the "traitor naib" and to support Circassian resistance to Russia (BOA, A. MKT. UM. 332/46). However, on 1 January 1860 during his visit to Shapsugh, Sefer Bey died suddenly; he was buried in the Vordobgach valley (Lapinskii 1863, 195). An old Circassian man, who knew the famous prince well, told Felitzyn that "Sefer Bey did not lose prestige in the eyes of the people, despite all the setbacks they experienced, and to the very last commanded great respect (Felitzyn 1904, 160)".

${ }^{29}$ In addition, he asked the Sultan to force Mehmed Bey (Janos Bangya de Illosfalva, a Hungarian colonel who had decamped to Turkey in 1845 and entered the Ottoman army) and his associates, Osman Ağa and Ali Ağa (who had recently and clandestinely proceeded to Circassia) to return immediately and punish them "to set an example for others." For more details, see FO 881/618, 98-99 and Lendvai 2003, 253-254.

30 See, BOA, İ. DH. 25156; i. MMS. 10/430; FO 195/528; FO 195/458; FO 78/1303; FO 78/1276; Kazem-Bek 1860, 239-240; Lapinskii 1863, 108-109. 
His son Karabatir succeeded him and styled himself the 'Commandant of Circassia' (FO 78/1503), continuing his father's policy. With part of his father's salary still coming from the Ottoman State, he tried to unite a number of Circassian groups against Russia, but in vain (Felitzyn 1904, 172). The Russians conquered Circassia after a series of military operations that some compared to wars of extermination and genocide. ${ }^{31}$ This phase was completed on 2 June 1864 (21 May, according to the old Russian calendar), with the Russian declaration of the final conquest of the Western Caucasus. During these years hundreds of thousands of Circassians were transferred by sea or by land to the Ottoman territories. But nearly half of those who left their homes in the hope of a new life in the Ottoman Empire died due to starvation or disease during the journey or shortly afterwards. ${ }^{32}$ Sefer Bey's ambition to found an independent Circassian state, with Anapa as its capital, did not materialize. ${ }^{33}$

\section{BIBLIOGRAPHY}

AKAK (AKTY SOBRANNYE KAVKAZSKOI ARKHEOGRAFICHESKOI KOMMISSIEI). 1885. Tiflis.

ALLEN, W.E.D. and P. Muratoff. 1953. Caucasian Battlefields: A History of the Wars on the Turco-Caucasian Border, 1828-1921, Cambridge: Cambridge University Press.

BADDELEY, J.F. 1908. The Russian Conquest of the Caucasus, London: Longmans, Green \& Co.

BADEM, C. 2010. The Ottoman Crimean War, 1853-1856, Leiden: Brill.

31 See Richmond 2013; Shenfield 1999, 149-162; Sarkisyanz 1974, 79, and Kazemzadeh 1974, 261-262.

32 About the Circassian exile, its extent and way of distribution throughout the Ottoman Empire, see Turgay 1990, 193-217; Inalcik 1983, 25; Pinson 1970; Rosser-Owen 2007; Karpat 1985, 27-70; Karpat 1990, 131-152; Kazemzadeh 1974, 262; Lewiss 1987, 96-123.

${ }^{33}$ Karabatir joined the Ottoman imperial forces and was awarded the rank of colonel. During the Russian-Ottoman war (1877-1878), he was entrusted with the command of the Circassian militia. In his retirement, the Sultan awarded him the title of pasha, gave him a house in Istanbul and granted him a pension. For more details, see Felitzyn 1904, 172-174. 
BAŞBAKANLIK OSMANLI ARŞIVI BOA), HAT, 27/1301; HAT, 188/8982; HAT, 29/1434; HAT, 271/13543; HAT, 26/1260; C. AS., 461/19233; C. AS., 1175/52380; C. AS., 700/29363; C. SM., 120/6033; C. MTZ., 19/907; C. MTZ, 4/160; C. ML., 48/2213; C. AS., 790/33473; C. ML., 24/1104; HAT., 653/31957; 1087/44240; HAT, 918/39971; HAT, 1103/44583; HAT, 1087/44240; HAT, 1087/44250C; HAT, 1102/44564; C. ZB., 58/2859; C. DH., 49/2413; HAT, 1179/46586; HAT, 1063/43640; HAT, 694/33477; HAT, 1421/58100; HAT, 754/35626; i. DH., 282/17709; HR. SYS., 1345/94; A. DVN., 94/2; HR. SYS., 1345/94; i. DH., 305/19355; HR. TO., 424/37; i. DH., 352/23196; i. HR., 140/7327; i. MMS., 9/366; i. DH., 25156; i. MMS., 10/430; A. MKT. UM., 332/46; A. MKT. NZD., 303/74; i. MMS., 18/799; i. MVL., 449/20018; A. MKT. MHM., 241/52; i. DH., 498/33843; A. MKT. MHM., 244/92.

BELL, J.S. 1840. Journal of a Residence in Circassia during the Years 1837, 1838 and 1839, London: Edward Moxon, 2.

BUDAK, M. 1993. 1853-1856 Kırım Savaşı'nda Kafkas Cephesi, Unpublished Ph. D. Thesis, Istanbul: İstanbul Üniversitesi.

CHIRG, A. 2002. Razvitie obshchestvenno - politicheskogo stroia adygov Severo-Zapadnogo Kavkaza, konets XVIII - 60-e gg. XIX v., Maikop: Kachestvo.

CLOWES, W.L, 1901. The Royal Navy: A History from the Earliest Times to the Present, London: Sampson Low, Marston \& Company, 6.

FELITZYN, E.D. 1904. “Kniaz Sefer-bei Zan. Politicheskii deyatel'I pobornik nezavisimosti cherkesskogo naroda", Kubanskii sbornik, Ekaterinodar, 10.

FOREIGN OFFICE 78/1336; FO 195/443; FO 97/344; FO 881/1441; FO 78/1243; FO 881/618; FO 78/1243; FO 195/528; FO 195/458; FO 78/1276; FO 78/1503.

GOSUDARSTVENNIY ARKHIV KRASNODARSKOGO KRAIA, f. 261, op. 1, d. 1263.

HATHAWAY, J. (ed) 2009. Al-Jabarti's History of Egypt, Princton, NJ: Markus Wiener Publishers.

HENZE, P.B. 1992. "Circassian Resistance to Russia", in Marie Bennigsen Broxup (ed.), The North Caucasus Barrier: The Russian Advance towards the Muslim World, London: C. Hurst \& Co.

INALCIK, H. 1983. “Čerkes”, EI², Vol. II, Leiden: E. J. Brill.

KARLGOF, N. 1860. "Magomet-Amin”, in Kavkazskii kaledar' na 1861 god, Tiflis.

KARLGOF, N. 1860. "O politicheskom ostroiistve cherkesskikh plemen, naselyayushchikh severo-vostochnyy bereg Chernogomoria", Russkii vestnik, 8. 
KARPAT, K.H. 1990. "The Hijra from Russia and the Balkans: The Process of Self-Definition in the Late Ottoman State" in Dale F. Eickelman and James Piscatori (eds. ), Muslim Travellers: Pligramage, Migration, and the Religious Imagination, London: Routledge.

KARPAT, K.H. 1985. Ottoman Population 1830-1914: Demographic and Social Characteristics, London: The University of Wisconsin Press.

KAZEM-BEK, M.A. 1860, "Mokhammed Amin", Russkoe Slovo, VI.

KAZEMZADEH, F. 1974, "Russian Penetration of the Caucasus," in Taras Hunczak (ed. ), Russian Imperialism from Ivan the Great to the Revolution, New Brunswick, New Jersey: Rutgers University Press

KERASHEV, A. 1995. "Politiches kaia deiatel'nost kniazia Sefer-Beia Zanoko v gody Kavkazskoi voiny", Rossiia Cherkesiia: vtoraia polovina XVIIIXIX vv., Maikop: Meoty.

KHAN-GIREI, 1989. Cherkesskie Predaniia, Nal'chik: Ël'brus.

KHOON, Y. 2012. "The Nā'ib and the Sadr-i A'zam: An Unpublished Letter from Muhammad Amin to the Ottoman Grand Vizier", Journal of Islamic Studies.

KHOON, Y. 2010. Sufism and Resistance: Muhammad Amin and the Circassian Anti-Colonial Struggle in the Northwest Caucasus in the midNineteenth Century, Ph. D. diss., Hebrew: HaifaUniversity.

KING, C. 1863. "Imagining Circassia: David Urquhart and the Making of North Caucasus Nationalism", The Russian Review, Vol. 66 [2], 2007.

LAPINSKII, T. 1863. Die Bergvölker des Kaukasus und ihr Freiheitskampf gegen die Russen, Hamburg: Hoffmann und Campe, Vol. 1.

LENDVAI, P. 2003. The Hungarians: A Thousand Years of Victory in Defeat, Princeton, N. J.: Princeton University Press.

LEWIS, N.N. 1987. Nomads and Settlers in Syria and Jordan, 1800-1980, Cambridge: Cambridge University Press.

LONGWORTH, J.A. 1840. A Year Among the Circassians, London: Henry Colburn, 2.

OSMAN BEY. 1877. "Vospominaniya 1855 goda", Kavkazskii Sbornik, 2, Tiflis.

PANESH, A. 1991. “Deiatel'nost' Khazhi-Magometai Suleimana-Ëfendiia na Severo-Zapadnom Kavkaze" in Cherkesiia v XIX veke, Maikop.

PINSON, M. 1970. Russian expulsion of mountaineers from the Caucasus, 1856-1866 and its historical background: Demographic warfare, an aspect of Ottoman and Russian policies, 1854-1866, unpublished PhD Thesis, Harvard University.

PROZRITELEV, G.N. 1998. "Posol'stvoot Shamilia k Abadzekham," in A.N. Osmanov, ed. Mukhammad-Amin iNarodno-Osvoboditel'noe Dvizhenie 
Narodov Severo-Zapadnogo Kavkaza v 40-60 gg. XIX veka (Sbornik Dokumentovi Materialov), Makhachkala: Jupiter.

RICHMOND, W. 2013. The Circassian Genocide, Rutgers University Press.

ROSSER-OWEN, S. and S. Isla. 2007. The First 'Circassian Exodus' to the Ottoman Empire (1858-1867), and the Ottoman response, based on the accounts of contemporary British observers, unpublished MA Thesis, London University.

SARKISYANZ, E. 1974. "Russian Imperialism Reconsidered," in Taras Hunczak (ed. ), Russian Imperialism from Ivan the Great to the Revolution, New Brunswick, New Jersey: Rutgers University Press.

SHENFIELD, S.D. 1999. "The Circassians: A Forgotten Genocide?"in Mark Levene and Penny Robert (eds.), The Massacre in History, New York: Berghahn Books.

SLADE, A. 1837. Turkey, Greece and Malta, London: Saunders \& Otley, 2.

SLADE, A. 1867. Turkey and the Crimean War: A Narrative of Historical Events, London: Smith, Elder \& Co.

SOKOLOV, D. 1905. "Khadzhi Magomet (Spodvizhnik Shamilia. Istoricheskaia spravka)", Kubanskii Sbornik, Ekaterinodar, XI.

SPENCER, E. 1837. Travels in Circassia, Krim Tartary, \&c. including a steam voyage down the Danube, from Vienna to Constantinople and round the Black Sea, in 1836, London: Henry Colburn, 2.

SPENCER, E. 1838. Travels in the Western Caucasus, Including A Tour through Imeretia, Mingrelia, Turkey, Moldavia, Galicia, Silesia, and Moravia, in 1836, London: Henry Colburn, 1.

THE FOREIGN OFFICE LIST, London: Harrison, 59, Pall Mall, 1856.

THE ILLUSTRATED LONDON NEWS, "Deputation of Circassian Chiefs to the Sultan", 24 May 1856.

TURGAY, Ü. 1990. "Circassian Immigration into the Ottoman Empire, 1856-1878, " in Wael B. Hallaq and Donald P. Little, Islamic Studies Presented to Charles J. Adams, Leiden: E. J. Brill.

URQUHART, D. 1837. The Portfolio: A Collection of State Papers and other Documents and Correspondence, Historical, Diplomatic, and Commercial, London: Frederic Shoberl, 5.

YAMA'UCHI, M. 1985. "From Ottoman Archives", Central Asian Survey, $4 / 4$. 